Julianna Ispánovics Csapó*

UDC 821.511.141(497.11):930.85

Faculty of Philosophy, DOI: 10.19090/gff.2017.1.119-134

University of Novi Sad

Pregledni naučni rad

\title{
THE HUNGARIAN LITERARY CULTURE IN SERBIA IN THE LIGHT OF BIBLIOGRAPHY ${ }^{* *}$
}

The aim of the study is to approach, examine and present the historical, theoretical and institutional frameworks and nature of the Hungarian literature in Serbia. The result of the research is a contextual narrative based on bibliographic data that analyses and summarises the literature of the region, its past and its present, in the context of linguistics and cultural studies, media, theatre and film. Contextuality is present in the relation to both Yugoslavian/Serbian literature and the literature of Hungary; it draws on the bibliographic corpus to outline the endeavours towards and relations with the literary culture of Hungary and the Yugoslavian/Serbian literary culture.

Keywords: Hungarian literary culture, bibliography, Serbia

\section{THE CONTEXTUAL NARRATIVE OF THE HUNGARIAN LITERARY CULTURE OF VOJVODINAIN THE LIGHT OF BIBLIOGRAPHY}

The Bibliographic Brochures of the Hungarian literature of Vojvodina (Pastyik, 1969-1989; Pohárkovics, 1990-1992; Csapó, 1993-1999; Ispánovics Csapó, 2001-2015) represent four decades of the contextual narrative of the Hungarian literary culture of Vojvodina, since "there is no community without a fully-developed culture" (Bányai, 2010). They outline the structure of book and library culture (with a special regard to reader education) and the pillars of the media (print media, television, radio and portals). They present the results of Hungarian linguistic research in Vojvodina, assert the difficulties and successes of teaching in Hungarian, document the achievements in cultural history (the history of churches, settlements, schools, arts, music, sports and sciences) and ethnography, encompassing folklore, theatre and film.

The overview of our book culture summarises the areas of bibliophilia ${ }^{1}$, bibliography, historical bibliography, typography, publishing and distribution,

\footnotetext{
*csapo@eunet.rs

** This paper has been written within the project no. 178017 that is financed by The Ministry of Education, Science and Technological Development of the Republic of Serbia.
} 
library science and press. Besides the general questions of book publishing, the bibliographic corpus reveals the sources of documenting the diverse profiles of older and newer Hungarian book publishers ${ }^{2}$ in Vojvodina, their work and publications. Besides the question of the distribution of domestic books, the domain of book distribution continuously raises the question of (text)book import from Hungary and traditional events popularizing books (book month, book week, book exhibitions and fairs). In the area of library science, we can get informed about the achievements in the library culture of Vojvodina, the vocational conference of our librarians in Senta, further trainings, the activities of the Kapocs Library Group, the regional "national library" function of the Institute for Hungarian Culture based in Senta and their activities, and about the Hungarian libraries in Vojvodina, and libraries with a Hungarica collection. The methodology of reader education and the events of the Hungarian movement for promoting reading in Vojvodina are both ongoing topics of our book culture. In the context of print media, the appearance of Hungarian daily and weekly periodicals (Magyar Szó, Családi Kör, Hét Nap), journals (Hungarológiai Közlemény, Tanulmányok, Létünk, Híd, Új Kép, Bácsország, Aracs, Módszertani Közlöny), yearbooks (Vajdasági Magyar Helytörténeti Társaság Évkönyve), calendars (Magyar Szó Naptára), region-specific periodicals, bilingual (seldom) multilingual journals, and the appearance of local papers from 1990 (Körkép from Ada = Panorama, Becsei Újság = Bečejski Mozaik, Dunatáj, Csernyei Újság, Muzslyai Újság, Temerini Újság, Új Kanizsai Újág, Szó-Beszéd from Mali Iđoš) is observed.

In the area of linguistic research, our literature appears in the context of contemporary fields of research that are typical in the region (historical linguistics, sociolinguistics, psycholinguistics, terminology, onomastics, contrastive linguistics, lexicography - with a special regard to bilingual dictionaries -, phonology, morphology, phraseology, syntax, pragmatics, bilingualism - educational and vocational -, the use of toponyms, language cultivation - general principles, general

1 Since 1994, the Beautiful Hungarian Book in Vojvodina Award of the Institute for Hungarian Culture in Vojvodina has been regularly awarded in Serbia as well.

2 Agape, Aracs Association of Tradition Protection, Bácsország, Faculty of Philosophy, Családi Kör, Dudás Gyula Museum and Circle of Penfriends, Híd, Forum Publisher, Grafoprodukt, Létünk, LOGOS, Magyar Szó, Hungarian Teacher Training Faculty, Open University, Temerini Újság, Tankönyvkiadó Intézet, Thurzó Lajos Educational Centre, Hungarian Cultural Institute of Vojvodina, Hungarian Higher-education Centre of Vojvodina, Hungarian Folk Center of Vojvodina, Hungarian Scientific Association of Vojvodina and zEtna. 
surveys and specific problems, and the Gábor Szarvas Linguistic Days). Maintaining and expanding education in the native language is of key importance for the Hungarian literary culture of Vojvodina as well. Because of this, our literary bibliography maintains a record of the up-to-date information relevant to the instruction in Hungarian (general surveys, laws, strategies, educational institutions, continuing professional training for the teachers, the civil sphere, the methodology of teaching Hungarian, and professional trainings and competitions).

The emergence and development of cultural history and ethnographic research in Vojvodina has a rich history and, from its beginnings (during the second half of the $19^{\text {th }}$ century) up until today, it provides a vivid context to our literary culture, always open to dialogue. The achievements within the history of the church, local history, i.e. the history of the settlements, the history of schools, fine arts, sports, science and music present a background to the narrative of the Hungarian literature of Vojvodina that is abundant in events, occurrences and creators. The fieldwork and research conducted by ethnographers complements the events of literary culture, its establishment and texts, with the corpora of folk stockfarming, crop farming, historical recollection, decorative art, the world of beliefs, folk religion, habits, folklore (ballads, legends, tales, anecdotes, idioms and proverbs), folk music and dance. The contemporary events of folk culture (Gyöngyösbokréta, Durindó, Öseink zenéje, Szólj, síp, szólj! and Lajos Kálmány Folk Tales Telling Competition), their civil counterparts (Lajos Kiss Ethnographic Society and the Hungarian Folk Centre of Vojvodina folklore houses) and educational and scientific events (ethnographic camps, festivals and scientific discussions) are significant in terms of our literary culture as well. The Hungarian theatrical life of Vojvodina has been one of the richest "environments" of our literature (as the research of the history of theatre shows), and it still remains that in our time. Besides the question of the productions in performing-arts, the functions of the theatre and its repertoire are debated, and the functioning of certain Hungarian theatres and theatre companies in Vojvodina (the Novi Sad Theatre, the Hungarian company of the Subotica National Theatre, the Kosztolányi Dezső Theatre, the András Urbán Company, the Children's Theatre of Subotica and the Hungarian Studio Theatre of Senta) are overseen, the events of the current season (tours, guest performances, festivals and competitions) are kept a record of, and the performances brought to stage are analysed and evaluated. Alongside the events of the domestic theatrical life, our literary bibliography looks at events in the neighbouring countries, in Hungary, the Hungarian parts of Romania, western parts populated by Hungarians, etc., as not only Hungarian and Yugoslav/Serbian playwrights and their plays, but also our actors and stage directors maintain a rich 
and multi-layered network of connections to abroad (guest performances, competitions, guest directions and reviews). In a minority context, the amateur theatrical life can have a determining role - and in this particular instance that is the case - in preserving language, identity and literature. The texts from our literature and Hungarian literature in general are often performed by Hungarian amateur theatres and theatre companies (Madách Amateur Theatre, Ferenc Berta Pocket Theatre) on stages across Vojvodina and during festivals and competitions.

The conventional intermedial connecting point of our literature is the film and cinematography of Vojvodina. The bibliography of the Hungarian literature of Serbia every year follows the events of the two most dignified film events, the Hungarian Film Review in Budapest and the International Film Festival in Palič, as well as the Hungarian Film Days of Vojvodina, and even the day of the Hungarian motion picture of Vojvodina. Our bibliography helps keep track and ensures the recognisability of the latest feature films and documentaries relevant to Hungary or Hungarians in Vojvodina.

The creations of our writers do not only live on in the form of film adaptions. Besides in print, the world of our literary culture is always accessible in the electronic media as well. The centre of the regional TV programmes in Hungarian is Novi Sad (Television of Vojvodina and Mozaik Television) and Subotica (Pannon RTV). The operation and continuity of the local television channels is nowadays chiefly possible due to private, cable television networks, which, depending on viewer demographics and their needs and as a result of business considerations, may provide several hours of news, entertainment or cultural programmes in Hungarian. The Hungarian viewers in Vojvodina regularly follow the broadcast of the Hungarian television channels. As a result of the this, the press coverage in Vojvodina of the most viewed channels (M2, TV2, Duna Televízió and RTL Klub) is growing year by year. Amongst the public service radios broadcasting in Vojvodina, those in Novi Sad (Radio of Vojvodina and Mozaik Radio) and in Subotica (Hungarian Radio and Pannon Radio) still have a leading role with their programmes in Hungarian. On the other hand, the number of local Hungarian radio broadcasts is also significant. Local radios in Hungarian operate in Temerin, Kula, Petrovaradin, Vrbas, Sombor, Bačka Topola, Bač, Kanjiža, Srbobran, Bečej, Ada and Odžaci. The broadcasting stations of Banat broadcast their programs from Novi Bečej, Zrenjanin, Sečanj, and Kovačica, Kikinda, Plandište and Kovin on a daily or weekly basis.

The Hungarian print and electronic media in Vojvodina is already available in the virtual space in a digital form in most cases. The first virtual medium was founded in 2003 by the former publicist of the Magyar Szó, Imre Sebestyén, who 
was not only the founder, but also the editor of the Vajdaság Ma news portal from Serbia. The "continuation" of the newspaper the Napló (1990-1997) from Novi Sad (ed. Károly Keszég), the first independent paper from Vojvodina, on the internet (naplo.org), has also started in May 2009 with Gábor Bódis as the editor.

\section{THE MATRIX OF OUR LITERARY CULTURE - AREAS, INSTITUTIONS, AUTHORS AND RELATIONS}

The institutionalization of the Hungarian literary theory of Yugoslavia/Vojvodina/Serbia can be tied to the formation of the Department of Hungarian Language and Literature in Novi Sad in 1959, and to its daughter organization, the Institute of Hungarology also based in Novi Sad, that functioned independently until 1976. The scientific journals of the department of the Faculty of Philosophy are the Tanulmányok [Studies] (1969-) and the Institute's the Hungarológiai Közlemény [Hungarological Release] (1969-). Both journals reflect the characteristic, preferred research areas and directions of our literature (Toldi, 2009).

The research within the Hungarian literary theory of Vojvodina mostly follows the contemporary trends and tendencies, relying in the past, for example, on the results of the modern (structuralist) studies of literary history, and applying the approaches and examining the issues of postmodernism today (regional culture, the new relation of the centre and periphery, space and time, intertextuality, intermediality, reception theory, deconstruction etc.).

In the field of literary criticism, the dominant world view is that of modernism, following the standards set by the ideology and creation processes of the avant-garde and neo-avant-garde, rejecting all other traditions (county, folk, national and civil), "proclaiming" and canonizing itself from the stronghold of the state-supported institutions (publishers and journals) into historical heritage. The model of the Hungarian literary criticism of Vojvodina is in tune with the perception that the modern movement dictates a "primitive and violent exterior normativity", and that "what is not modern is out-of-date. Who/what does not stand for progressiveness (the newer step in modernism), justifiably ends up on the periphery. Normativity coming from outside is not able to handle the primordial difference, and can easily lose value in the judgement of novelties. Normativity that simplifies things excludes the ones not fitting the box, unnecessarily simplifies, and loses energy as a result" (Faragó, 1991: 8). The aggressiveness of the tendency presented above brings into life the postmodern endeavours organized around the DNS post cultural journal in Novi Sad, the circle of those young authors, who make 
the formal or axiomatic logic of modernism and its simple rationality complete and humanlike by the involvement of the emotions and intuitions, stepping past "the conflict of tradition and modernity" (Bányai, 2010).

The principle topic of Hungarian writings about literary politics in Serbia is the authorial ownership, the responsibility of the authors. The contrasts between the artist's role in the society, the ideological constraint and artistic freedom and aesthetic determination generate continuous, occasionally generation-wide debates in our literature.

Imre Bori synthesized the Hungarian literature of Yugoslavia. His work in literary history comes into existence in several stages, several editions ${ }^{3}$ and after extended grounding, as the outcome of a series of studies. He contemplates the past of our literary culture and the contemporary literature originating from it, in the context of society and the cultural history of the region.

Following and presenting the events, phenomena and authors of the contemporary Yugoslavian/Serbian literature in Hungarian is a separate chapter in the bibliography of the Hungarian literature of Serbia. Apart from the region, contemporary literary topicalities from Hungary and beyond the borders (mainly from Transylvania) are also present and affect our literary culture.

The relations established with other surrounding literatures are the topic of the Hungarian comparative literature in Vojvodina that, of course, researches the effects, relations, and parallels with the world literature as well. Nevertheless, its most frequent area of research are the bi-directional South Slavic-Hungarian literary relations. Folk culture, the Hungarian literature of the $19^{\text {th }}$ and $20^{\text {th }}$ centuries,

${ }^{3}$ A jugoszláviai magyar irodalom története 1918-tól 1945-ig.[History of the Hungarian literature of Yugoslavia between 1918-1945] Novi Sad, Forum Könyvkiadó, 1968. Fejezetek irodalmunk természetrajzából.[Chapters from the natural history of our literature.] Novi Sad, Forum Könyvkiadó, 1973. Irodalmunk évszázadai. [Centuries of our literature] Novi Sad, Forum Könyvkiadó, 1975. A jugoszláviai magyar irodalom rövid története. [Short history of the Hungarian literature of Yugoslavia] Novi Sad, Forum Könyvkiadó, 1982. A jugoszláviai magyar irodalom rövid története. [Short history of the Hungarian literature of Yugoslavia] Novi Sad, Forum Könyvkiadó, 1983. A jugoszláviai magyar irodalom rövid története. [Short history of the Hungarian literature of Yugoslavia] Novi Sad, Forum Könyvkiadó, 1993. A jugoszláviai magyar irodalom története. [History of the Hungarian literature of Yugoslavia] Novi Sad, Forum Könyvkiadó, Zavod za izdavanje udžbenika, 1998. A jugoszláviai magyar irodalom története. [History of the Hungarian literature of Yugoslavia] Novi Sad, Forum Könyvkiadó, 1999. A jugoszláviai magyar irodalom története. [History of the Hungarian literature of Yugoslavia] Novi Sad, Forum Könyvkiadó, 2007. 
provides a rich resource on the relation of the Serbian-Hungarian and CroatianHungarian literatures. In addition to this, literary translation is of paramount importance to the Hungarian literary culture of Vojvodina. The bridge role of our literature mentioned so frequently is primarily realized through the translation of Hungarian texts into the South Slavic languages and the translation of the South Slavic literature into Hungarian. Theoretical works, translation essays and notes help in the practice of literary translation, searching for the solutions to the various literary translation problems by thematising the translatability of the literary form of expressions and cultures behind the literature.

The understanding reader, the recipient, is the basis of the literature. The state of teaching Hungarian literature in Vojvodina can be inferred from our bibliography. The methodological journal titled Új Kép helps with modern lesson plans, and also motivates the work of the Hungarian language teachers working in Serbian primary schools and high-schools. The practice of literature education with digital devices is already present in our educational system. On the other hand, the examination of the literary forming effects of the virtual text and its application in education is essential for the development of our literary culture, besides the syllabus and method of text understanding through visuality and experience-centred literature education. The process of literary history and turning the literary text into an experience is a constant challenge. How to teach modern and contemporary (postmodern) authors? What can we do today with the authors of the old Hungarian literature? Besides the methodological guidance, our bibliography follows closely the continuing professional training of the Hungarian teachers in Vojvodina (courses and summer schools), the programs realised in out-of-school literary workshops and camps for primary school and high-school students.

The organizational and institutional frameworks of the Hungarian literary culture and literary life in Vojvodina (Yugoslavia) began to form towards the end of the 1950s. In 1957, the Forum Publisher was founded. Since 1959, the Híd Literary Prize is being awarded. The Hungarian literary scholars and writers of fiction from Vojvodina also become members of the Academy of Sciences and Art of Vojvodina. Besides its scientific and educational role, the Department of Hungarian Language and Literature in Novi Sad begins its work on the promotion and popularization of literature and culture. The department's programmes are manifold (programmes for national celebratory days (15 March), poetry day programmes, Kontaktzóna - encounters with fiction and scientific writers, artists, book presentations, science popularization through faculty programmes, university festivals and translation workshops). 
Among the important events of the Hungarian literary life of Vojvodina are the announcements of various literary competitions ${ }^{4}$, their organisation and publication of the prizewinning texts.

The endeavours of the older and younger generation of authors presenting their literary work or the efforts of writers at the beginning of their career are acknowledged by the expert readers ${ }^{5}$ of our literature through the distribution of literary awards.

Founding and operating Hungarian literary societies in Vojvodina has been a problem area in our literary culture from the very beginning. Except for the Térzene Artistic and Literary Association in Senta, the only other such society is the Pataki László Literary and Artistic Association in Subotica. Neither of them is truly capable to unite the Serbian Hungarian authors, as our authors are committed to the Writers' Union of Vojvodina (Novi Sad) and the Hungarian Writers' Association (Budapest) as well.

The writers' camp in Kanjiža founded in 1953 is the one of the widely recognized and respected events of the Hungarian literary life in Yugoslavia. The multitudinous series of literary programmes has successfully brought together the authors of the region for a long time. The zEtna online journal from Senta launched a series of virtual writers' camps in 2000, a Literary (textual) "founding of cities" in the virtual space, which is later expanded by traditional of writer camps and a contemporary literary festival.

Book presentations, author-reader meetings, literary recitals, and, last but not least, literary memorial days, constitute the traditional events of our literary life. Memorial days are an efficient device of popularizing literature, since our programmes ${ }^{6}$ encompass the region.

${ }^{4}$ Novel competition of the Forum Publisher (Novi Sad), Mihály Majtényi short-story competition (Novi Sad), János Herceg short-story competition (Sombor), Nándor Gion belletrist competition (Srbobran-Novi Sad).

${ }^{5}$ Híd Literary Prize (1959-, Híd Journal, Novi Sad), Ervin Sinkó Literary Prize (1970- , Ervin Sinkó Foundation, Department of Hungarian Language and Literature, Novi Sad), Kornél Szenteleky Literary Prize (1972- , Sivac), Bazsalikom Translator Prize (1972- , Sivac), Károly Szirmai Literary Prize (1976-, Temerin, Vrbas), István Koncz Literary Prize (Vajdasági Írók Egyesülete, Association of Writers from Vojvodina, Novi Sad), János Sziveri Literary Prize (1991-, Budapest).

${ }^{6}$ Imre Csépe - Memorial Day, Mali Iđoš; Kornél Szenteleky Literary Days, Sivac; Dezső Kosztolányi Literary Memorial Days, Subotica; György B. Szabó - Memorial Days, Zrenjanin; Erzsébet Juhász - Memorial Day, Bačka Topola; Ferenc Herczeg Days, Vršac; 
Two of our traditional programmes, the KMV (Középiskolások Müvészeti Vetélkedője) High School Art Competition and, from 2002, the ÁMV (Általános Iskolák Múvészeti Vetélkedője) Primary School Art Competition in Subotica provide an opportunity for young authors and artists to present themselves and their work. The KMV, founded in 1966/67 in Bečej, grew from a literary competition into an artistic movement that hosts artists, folk musicians, actors, film-makers and poem singers in the Bečej-Bačka Topola-Temerin-Senta area.

Creators, fiction and scientific writers live, create and publish their texts in the context of the institutional system, programmes and events of the Hungarian literary culture in Serbia. They Hungarian minority literature coexists with the conflicts in our literature, the debates of tradition and modernity, with the necessary evil, because "the existence of the minority literary and cultural canon and its standard can be found in it" (Bányai, 2010). The existence and presence of a critical attitude is undoubtedly an important driving force and formative force of the literary life, but can we speak about genuine, productive dialogues, open to diversity when looking at the phenomena and tendencies of the Hungarian literature in Vojvodina both from historical as well as a contemporary viewpoint? Has there ever been, or is there a true willingness to listen to each other, or it is merely a rhetoric strategy?

István Margócsy disrupts the idea of a homogeneous image of the historical literary tradition, the "magic utopia of the literary historical unit" (Margócsy, 2012: 2 ), when he draws attention to the fact that the literary historical syntheses and narratives directed by principles outside of literature create the untraceable, but (considered to be) existing continuity of literary history, the thought of a "developmental or unfolding scheme" (Margócsy, 2012: 3). The homogeneous model of the cultural and literary national history was formed by certain authors of the diachronic narratives with the help of a scientific directing principle as a result of the scientific thinking of their age by the means of analogy:

.... a preconceived (proved to work by others) developmental order dominates; its unity and element-wise structure being unquestionable - as the "big" history has its own prewritten course, the same regularities and effects have to be reflected in literature as well - and if they do not exist, then it is necessary to create them (Margócsy, 2012: 3).

József Podolszki Literary Memorial day, Feketić; Ferenc Tóth - Memorial Day, Bačka Topola; Dániel Papp - Memorial Day, Stara Moravica. 
Instead of the desire for the uniformity and continuity of the literary entities, events, and processes, Margócsy considers the discontinuity and fragmentation of the literary set as the principal feature of literary history. This is especially true, he emphasizes, if we include the texts' history of reception into the net of the historical narratives. This idea can be related to the entirety of Hungarian literature and culture appearing in time and space. He solves the problem of handling the literature and culture beyond the borders. The "plurality of historicism" (literary histories and cultural histories) makes the fiction of a diverse "historical sequence" possible (Margócsy, 2012: 5).

Margócsy's theory is applicable to Hungarian literature in Vojvodina as well, since instead of a continuous literary culture, we can rather talk about fragmented, continuously restarting domains of culture that frequently superficially acknowledge each other (if they do), and stand apart from each other by getting enmeshed in the debate between tradition and modernity. Although Kornél Szeneteleky and the Pécs emigration incorporate the county literary culture looking at Europe, Budapest and the South Slavic literary and cultural events (Ispánovics Csapó, 2012), they do not consider it equal, and by that they spread the trauma of the absence of tradition in our literature (Hózsa, 2010) which makes its destructive influence felt up to this date. The new times following World War II establish the model of national literature lead by the communist ideology after abolishing "the rudimental bourgeois culture", Szeneteleky's literary heritage. The modern world view and literary culture unfolding in the 1960s makes an attempt at an extensive deconstruction, since it rejects not only the previous era, but its entire pre-history when it accepts only the European cultural and literary pattern either directly, or with the mediation of the Yugoslav translation literature. Our history of literature considers this the era of the neo-avant-garde, the ideological heritage of which is not rejected though by the carefully forming Hungarian postmodern of Vojvodina, but merely considered as one of the acceptable traditions.

Are the inner conflicts and debates of our literature joined by the intermediary political, historical, cultural situation, the replication of the efforts and relationships with the world literature, the literature of Hungary and the Yugoslavian/Serbian literary culture - bridge roles or something else - intercultural contacts and integration pressings, aptitudes, constraints?

The integration of the heterogeneous minority literatures in the Carpathian Basin is beneficial to Hungarian culture as well, because "The natural integration of the minority and western Hungarian literatures into the Hungarian literature has made the image of the national self of the Hungarian literature complete and complex" (Görömbei, 2010). The heterogeneity and the eclectic national culture is a 
stable identity forming element and it is a sustaining force of national identity in the face of globalisation (Görömbei, 2010). This is especially true when the integration of the minority language varieties, literatures and cultures is not governed by the centre, but by such liberal cultural policy strategies that urge the integration of the minority literatures living and developing in intermediary situations while keeping their respective regional linguistic, literary and cultural features.

\section{CONCLUSION}

The research into Hungarian literary history and theory in Vojvodina mostly follows the contemporary trends and tendencies. In the past they relied on the results of the modern (structuralist) theory of literature, and nowadays they utilize the means of the postmodern approach. By examining the Hungarian literary history of Vojvodina, we find István Margócsy's theory, based on which we do not talk about a linear, continuous literary culture, much rather we talk about a fragmented history, and continuously restarting culture domains in the history of our literature, applicable. In the field of literary criticism, the dominant world view is still that of modernism. The key topics of political writings are the debates concerning the problems of literary role taking, overcoming the ideological constraints and validating the aesthetic governing principles.

The contemporary literary topicalities outside of the region, from Hungary and beyond the borders (mainly from Transylvania), are also present and influence our literary culture. The Hungarian comparative literature of Vojvodina also researches the effects of world literature, its effects, relations, parallels, but its most developed field is still the South Slavic-Hungarian literary relations.

\section{Julijana Išpanović Čapo}

\section{KNJIŽEVNA KULTURA MAĐARA U SRBIJI U KONTEKSTU BIBLIOGRAFIJE}

\section{Sažetak}

Studija donosi pregled, analizu i prikaz istorijskih, teorijskih i institucionalnih osnova i karakteristika mađarske književnosti u Srbiji. Rezultat istraživanja teme vezane za književnu kulturu Mađara u Srbiji, pomoću stručne bibliografije, prikazuje istoriju, ali i savremenu mađarsku književnost regije. Analiza i sinteza materijala se vrše u kontekstu mađarske lingvistike, nauke o istoriji kulture, kao i u kontekstu medija, pozorišta i filma. Mađarska književnost u Srbiji ispitivana je u odnosu na književnosti u Republici Mađarskoj, ali i u odnosu na jugoslovensku/srpsku književnost. Korpus bibliografije mađarske književnosti u Srbiji omogućava detaljno ispitivanje kulturnih veza mađarske i jugoslovenske/srpske književne kulture.

Ključne reči: književna kultura Mađara, bibliografija, Srbija 
Ispánovics Csapó Julianna

A SZERBIAI MAGYAR IRODALMI KULTÚRA A BIBLIOGRÁFIA TÜKRÉBEN

Rezümé

A tanulmány célja a szerbiai magyar irodalom történeti, elméleti, intézményi mibenlétének, kereteinek megközelítése, vizsgálata és bemutatása. A kutatás eredménye egy olyan kontextuális narratíva, amely a térség irodalmát, annak múltját és jelenét, a szakbibliográfia segítségével a nyelv- és a kultúratudományok, a média, a színház, a film kontextusában elemzi és összegzi. A kontextualitás az anyaországi és a délszláv/szerb irodalmak vonatkozásában is tetten érhető, a bibliográfiai korpusz alapján megrajzolja az anyaországi és a jugoszláviai/szerbiai irodalmi kultúra felé mutató törekvések, kapcsolatok mintázatát is.

Kulcsszavak: magyar irodalmi kultúra, bibliográfia, Szerbia

\section{PUBLICATIONS}

Pastyik, L. (1969) A jugoszláviai magyar folyóiratok és lapok 1968. évi magyar irodalomtörténeti repertóriuma. [The 1968 Hungarian literary history directory of Hungarian periodicals and papers in Yugoslavia] Novi Sad: Hungarológiai Intézet

Pastyik, L. (1970) A jugoszláviai magyar folyóiratok és lapok 1969. évi magyar irodalomtörténeti repertóriuma. [The 1969 Hungarian literary history directory of Hungarian periodicals and papers in Yugoslavia] Novi Sad: Hungarológiai Intézet

Pastyik, L. (1971) A jugoszláviai magyar irodalom 1970. évi bibliográfiája. [The 1970 bibliography of the Hungarian literature in Yugoslavia] Novi Sad: Hungarológiai Intézet

Pastyik, L. (1974) A jugoszláviai magyar irodalom 1971. évi bibliográfiája. [The 1971 bibliography of the Hungarian literature in Yugoslavia] Novi Sad: Hungarológiai Intézet

Pastyik, L. (1974) A jugoszláviai magyar irodalom 1972. évi bibliográfiája. [The 1972 bibliography of the Hungarian literature in Yugoslavia] Novi Sad: Hungarológiai Intézet

Pastyik, L. (1975) A jugoszláviai magyar irodalom 1973. évi bibliográfiája. [The 1973 bibliography of the Hungarian literature in Yugoslavia] Novi Sad: Hungarológiai Intézet

Pastyik, L. (1975) A jugoszláviai magyar irodalom 1974. évi bibliográfiája. [The 1974 bibliography of the Hungarian literature in Yugoslavia] Novi Sad: Hungarológiai Intézet 
Pastyik, L. (1977) A jugoszláviai magyar irodalom 1975. évi bibliográfiája. [The 1975 bibliography of the Hungarian literature in Yugoslavia] Novi Sad: A Magyar Nyelv, Irodalom és Hungarológiai Kutatások Intézete

Pastyik, L. (1978) A jugoszláviai magyar irodalom 1976. évi bibliográfiája. [The 1976 bibliography of the Hungarian literature in Yugoslavia] Novi Sad: A Magyar Nyelv, Irodalom és Hungarológiai Kutatások Intézete

Pastyik, L. (1979) A jugoszláviai magyar irodalom 1977. évi bibliográfiája. [The 1977 bibliography of the Hungarian literature in Yugoslavia] Novi Sad: A Magyar Nyelv, Irodalom és Hungarológiai Kutatások Intézete

Pastyik, L. (1982) A jugoszláviai magyar irodalom 1978. évi bibliográfiája. [The 1978 bibliography of the Hungarian literature in Yugoslavia] Novi Sad: A Magyar Nyelv, Irodalom és Hungarológiai Kutatások Intézete

Pastyik, L. (1982) A jugoszláviai magyar irodalom 1979. évi bibliográfiája. [The 1979 bibliography of the Hungarian literature in Yugoslavia] Novi Sad: A Magyar Nyelv, Irodalom és Hungarológiai Kutatások Intézete

Pastyik, L. (1983) A jugoszláviai magyar irodalom 1980. évi bibliográfiája. [The 1980 bibliography of the Hungarian literature in Yugoslavia] Novi Sad: A Magyar Nyelv, Irodalom és Hungarológiai Kutatások Intézete

Pastyik, L. (1984) A jugoszláviai magyar irodalom 1981. évi bibliográfiája. [The 1981 bibliography of the Hungarian literature in Yugoslavia] Novi Sad: A Magyar Nyelv, Irodalom és Hungarológiai Kutatások Intézete

Pastyik, L. (1984) A jugoszláviai magyar irodalom 1982. évi bibliográfiája. [The 1982 bibliography of the Hungarian literature in Yugoslavia] Novi Sad: A Magyar Nyelv, Irodalom és Hungarológiai Kutatások Intézete

Pastyik, L. (1986) A jugoszláviai magyar irodalom 1983. évi bibliográfiája. [The 1983 bibliography of the Hungarian literature in Yugoslavia] Novi Sad: A Magyar Nyelv, Irodalom és Hungarológiai Kutatások Intézete

Pastyik, L. (1987) A jugoszláviai magyar irodalom 1984. évi bibliográfiája. [The 1984 bibliography of the Hungarian literature in Yugoslavia] Novi Sad: A Magyar Nyelv, Irodalom és Hungarológiai Kutatások Intézete

Pastyik, L. (1989) A jugoszláviai magyar irodalom 1985. évi bibliográfiája. [The 1985 bibliography of the Hungarian literature in Yugoslavia] Novi Sad: A Magyar Nyelv, Irodalom és Hungarológiai Kutatások Intézete

Pohárkovics, E. (1992) A jugoszláviai magyar irodalom 1986. évi bibliográfiája. [The 1986 bibliography of the Hungarian literature in Yugoslavia] Novi Sad: A Magyar Nyelv, Irodalom és Hungarológiai Kutatások Intézete, Forum Könyvkiadó 
Pohárkovics, E. (1990) A jugoszláviai magyar irodalom 1987. évi bibliográfiája. [The 1987 bibliography of the Hungarian literature in Yugoslavia] Novi Sad: A Magyar Nyelv, Irodalom és Hungarológiai Kutatások Intézete

Csapó, J. (1993) A jugoszláviai magyar irodalom 1988. évi bibliográfiája. [The 1988 bibliography of the Hungarian literature in Yugoslavia] Novi Sad: A Magyar Nyelv, Irodalom és Hungarológiai Kutatások Intézete, Forum Könyvkiadó

Csapó, J. (1993) A jugoszláviai magyar irodalom 1989. évi bibliográfiája. [The 1989 bibliography of the Hungarian literature in Yugoslavia] Novi Sad: A Magyar Nyelv, Irodalom és Hungarológiai Kutatások Intézete, Forum Könyvkiadó

Csapó, J. (1994) A jugoszláviai magyar irodalom 1990. évi bibliográfiája. The 1990 bibliography of the Hungarian literature in Yugoslavia] Novi Sad: Magyar Tanszék, Forum Könyvkiadó

Csapó, J. (1995) A jugoszláviai magyar irodalom 1991. évi bibliográfiája. [The 1991 bibliography of the Hungarian literature in Yugoslavia] Novi Sad: Magyar Tanszék, Forum Könyvkiadó

Csapó, J. (1996) A jugoszláviai magyar irodalom 1992. évi bibliográfiája. [The 1992 bibliography of the Hungarian literature in Yugoslavia] Novi Sad: Magyar Tanszék, Forum Könyvkiadó

Csapó, J. (1997) A jugoszláviai magyar irodalom 1993. évi bibliográfiája. [The 1993 bibliography of the Hungarian literature in Yugoslavia] Novi Sad: Magyar Tanszék, Forum Könyvkiadó

Csapó, J. (1998) A jugoszláviai magyar irodalom 1994. évi bibliográfiája. [The 1994 bibliography of the Hungarian literature in Yugoslavia] Novi Sad: Magyar Tanszék, Forum Könyvkiadó

Csapó, J. (1999) A jugoszláviai magyar irodalom 1995. évi bibliográfiája. [The 1995 bibliography of the Hungarian literature in Yugoslavia] Novi Sad: Magyar Tanszék, Forum Könyvkiadó

Ispánovics Csapó, J. (2001) A jugoszláviai magyar irodalom 1996-1997. évi bibliográfiája. [The 1996-1997 bibliography of the Hungarian literature in Yugoslavia] Novi Sad: Magyar Tanszék, Forum Könyvkiadó

Ispánovics Csapó, J. (2005) A jugoszláviai magyar irodalom 1998-1999. évi bibliográfiája. [The 1998-1999 bibliography of the Hungarian literature in Yugoslavia] Novi Sad: Magyar Tanszék, Forum Könyvkiadó

Ispánovics Csapó, J. (2009) A jugoszláviai magyar irodalom 2000-2001. évi bibliográfiája. [The 2000-2001 bibliography of the Hungarian literature in Yugoslavia] Novi Sad: Filozofski fakultet 
Ispánovics Csapó, J. (2010) A jugoszláviai magyar irodalom 2002. évi bibliográfiája. [The 2002 bibliography of the Hungarian literature in Yugoslavia] Novi Sad: Filozofski fakultet

Ispánovics Csapó, J. (2011) A jugoszláviai magyar irodalom 2003. évi bibliográfiája. [The 2003 bibliography of the Hungarian literature in Yugoslavia] Novi Sad: Filozofski fakultet

Ispánovics Csapó, J. (2014) A jugoszláviai magyar irodalom 2004. évi bibliográfiája. [The 2004 bibliography of the Hungarian literature in Yugoslavia] Novi Sad: Filozofski fakultet

Ispánovics Csapó, J. (2015) A jugoszláviai magyar irodalom 2005. évi bibliográfiája. [The 2005 bibliography of the Hungarian literature in Yugoslavia] Novi Sad: Filozofski fakultet

\section{REFERENCES}

Bányai, J. (2010) Hagyomány és modernitás konfliktusa. A kisebbségi kulturális kánon [The conflict of tradition and modernity. The minority cultural canon]. In: Irodalom, nemzet, identitás. [Literature, nation, identity], eds. József Jankovics and Judit Nyerges. Budapest: Nemzetközi Magyarságtudományi Társaság.

http://mek.oszk.hu/08100/08170/html/\#23. Downloaded: 10 March 2016

Bori, I. (1998) A jugoszláviai magyar irodalom története [History of the Yugoslavian Hungarian literature]. Novi Sad: Forum Könyvkiadó.

Faragó, L. (1991) Posztmodern. A modernizáció kritikája, avagy új kihívás.

[Postmodern. Criticism of modernisation, in other words a new challenge].

Tér és Társadalom, 4. 1-16.

http://tet.rkk.hu/index.php/TeT/article/view/223/445. Downloaded: 29 March 2016

Görömbei, A. (2010) Az irodalom szerepe a magyar nemzeti tudat kialakításában. [The role of literature in forming the Hungarian national consciousness]. In: Irodalom, nemzet, identitás. [Literature, nation, identity] eds. József Jankovics and Judit Nyerges. Budapest, Nemzetközi Magyarságtudományi Társaság. http://mek.oszk.hu/08100/08170/html/\#23. Downloaded: 10 March 2016

Hózsa, É. (2010) Trauma és irodalom - A tékozlás tünetei? A mai vajdasági magyar próza és a perem-trauma kultúrája [Trauma and literature - the symptoms? of extravagance The culture of the contemporary Hungarian prose in Vojvodina and that of the border- trauma]. In: Irodalom, nemzet, identitás. 
[Literature, nation, identity ], eds. József Jankovics, Judit Nyerges. Budapest, Nemzetközi Magyarságtudományi Társaság, http://mek.oszk.hu/08100/08170/html/\#23. Downloaded: 10 March 2016 Ispánovics Csapó, J. (2012) 80 éves a Kalangya. A bácskai kultúra „hasznosulása” Szenteleky Kornél Kalangyájában. [Kalangya is 80 years old. The culture of Bačka becoming valuable in Kornél Szenteleky’s]. Bácsország, 8: 100104.

Margócsy, I. (2012) Variánsok lehetséges és létező összefoglaló magyar irodalomtörténetekröl. [Variants on potential and existing comprehensive Hungarian literary histories]. Alföld, 3. http://www.alfoldfolyoirat.hu/node/341. Downloaded: 2 October 2013

Toldi, É. ed. (2009) Ötvenéves a Magyar Nyelv és Irodalom Tanszék [The Department of Hungarian Language and Literature is fifty-year-old]. Novi Sad: Faculty of Philosophy 